\title{
Uncomplicated crown fracture management
}

\author{
Dr. Niher Tabassum Siddiqua ${ }^{1 *}$, Dr. Fahd A.A. Karim², Dr. MD. Toufiqur Rahman ${ }^{3}$, Dr. Abdullah Al-Mamun ${ }^{4}$
}

\section{AFFILIATION:}

1. Dr. Niher Tabassum Siddiqua Snigdha MSc in Pediatric Dentistry (on course), Universiti Sains Malaysia Mail: nihar0088@gmail.com

2. Dr. Fahd A.A. Karim

Assistant Professor of Department of Conservative Dentistry and Endodontics, Update Dental College and Hospital Mail:fahdkarim1792@gmail.com

3. Dr. MD. Toufiqur Rahman

MSc in Pediatric Dentistry (on course), Universiti Sains Malaysia

Senior Lecturer,

Update Dental College and Hospital

Mail:dr.toufiqurrahman1987@gmail.com

4. Dr. Abdullah Al-Mamun

Intern Doctor,

Update Dental College and Hospital.

Mail:drmamunbinaftab@gmail.com

\section{Article info.}

Received: 17 January 2021

Accepted: 23 February 2021

Volume: Vol-11, Issue-1, April 2021

DOI: https://doi.org/10.3329/updcj.v11i1.53004

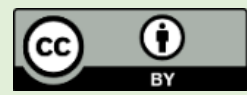

(C) Authors retain copyright and grant the journal right of first publication with the work simultaneously licensed under Creative Commons Attribution License CC - BY 4.0 that allows others to share the work with an acknowledgment of the work's authorship and initial publication in this journal.

https://creativecommons.org/licenses/by/4.0/

Publisher: Update Dental College, Dhaka, Bangladesh

Web: www.updatedentalcollege.edu.bd

E-mail: updcj@hotmail.com

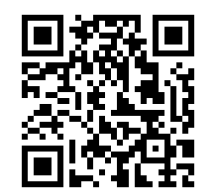

Scan QR code to see the latest issue

* Corresponding Author

Dr. Niher Tabassum Siddiqua Snigdha

MSc in Pediatric Dentistry (on course),

Universiti Sains Malaysia

Mail: nihar0088@gmail.com

\begin{abstract}
:
Background: Trauma-related injuries of the maxillofacial region occur more often these days and dentists are facing this condition frequently in their regular practice life. Traumatic dental injuries affects the same region with different frequencies in different age groups. It should be noted that upper central incisors are mostly traumatized by injuries compare to the other incisors. The maxillary central incisors were about $72 \%$, while premolars, canine, mandibular incisors, the upper lateral incisors injury rate is up to $8 \%$. A strong impact most often affects the crown and a weak and dull impact on the root apical direction and may result in avulsion of tooth and root fracture. Dental injuries caused by trauma have been an emergency condition, treatment options depend on the severity of injuries and clinical condition of the tooth at that moment. Combination treatment for a traumatic fracture of the tooth includes fixation of the tooth, the performance of surgical manipulation, determination of the need for endodontic treatment, restoration, and orthodontic consultations. Problem: In our case patient has an uncomplicated crown fracture. Solution: Direct composite restoration.
\end{abstract}

\section{KEYWORDS: Fracture, composite resin, aesthetic,}

\section{INTRODUCTION}

Maxillary incisor fracture is very common due to trauma, this incidence of injuries in dental hard tissue is about $18 \%$ to $22 \%{ }^{(1)}$. And $28 \%-44 \%$ of cases are uncomplicated fractures without involving the dental pulp(1). The 1st concern will be the management of these types of cases including restoration of normal function as well as aesthetic rehabilitation. The advanced technology, providing the clinician option to select from, but a direct composite restoration is a very simple and cost-effective treatment option ${ }^{(2)}$. On the other hand, resin restorations have many disadvantages. Marginal fracture, debonding, and discoloration are the most common causes of composite failure, and it's about $19 \%$ to $25 \%$ (3) . In many cases reattachment of the fractured tooth is also an option ${ }^{(4)}$. But most of the time fractured fragment is unavailable. However, in our case, direct composite restoration is a cost-effective aesthetic, and sweet table for the patient.

\section{CASE REPORT:}

A 30 years old male attended our clinic with the principal complaint of broken maxillary incisor teeth and wanted treatment on the same tooth. The patient explains his history of trauma a few years back due to biting on hard food. No relevant history was recorded. On clinical examination, the tooth seemed to have a fracture involving enamel and dentin without any other craze lines and no insolvent of pulp. Electric pulp testing and thermal pulp testing were performed on the tooth and no mobility was found with healthy soft tissue surrounding.

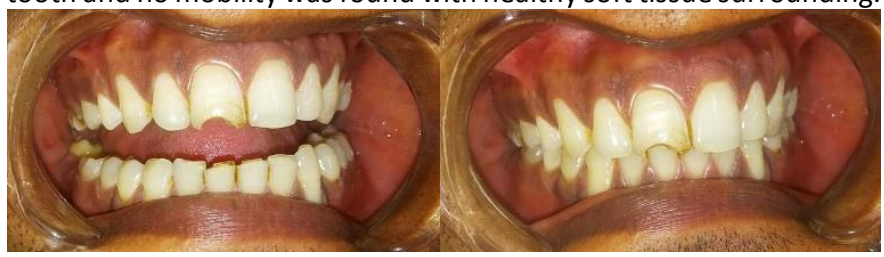

Figure 1: Before Rubber Dam Application ( Open View), Figure 2: Before Rubber Dam Application ( Close View)

For isolation of fractured tooth rubber dam was placed. Shade was selected carefully. The fractured area of the tooth was roughened by 
a fissure bur. $37 \%$ of ortho-phosphoric acid was used for etching the fractured part of the tooth for 15 seconds ${ }^{(2)}$. The tooth was then rinsed thoroughly with water for the double-time of etching and the excess water was shocked with dry cotton. Next, the adhesive primer and bonding were applied on the etched surface, air-thinned, and light-cured for 15-20 seconds using an LED light ${ }^{(2)}$.
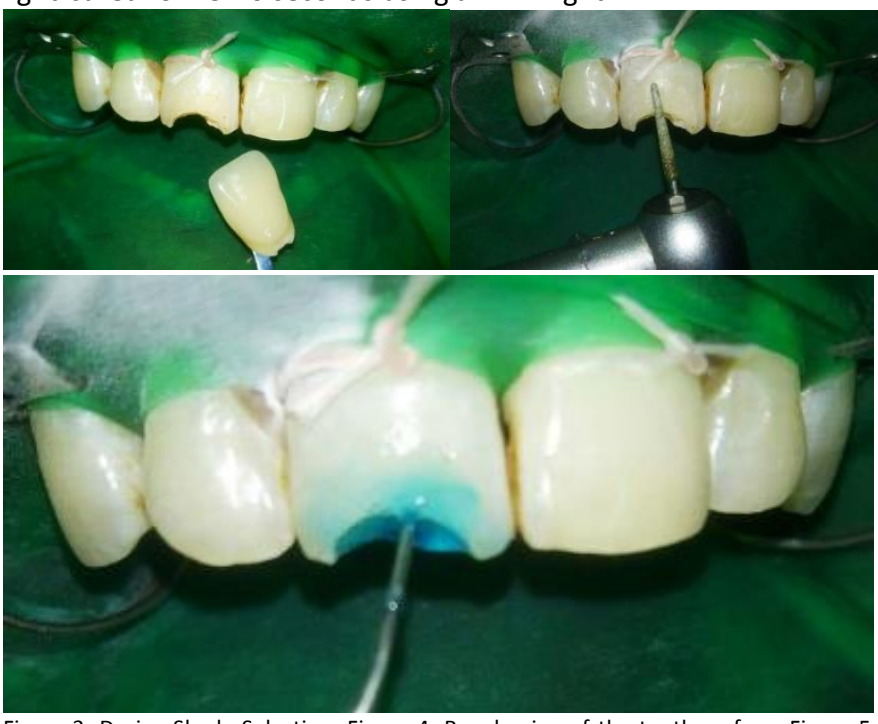

Figure 3: During Shade Selection, Figure 4: Roughening of the tooth surface, Figure 5 During Etiching

Finally, the composite resin was applied on the fractured part of the tooth with a non-stick stainless steel spatula, free handly. The composite was applied incrementally up to $1 \mathrm{~mm}$ thickness and cured by an LED light ${ }^{(2)}$. The tooth shape was given free handly and carefully. This procedure is time-consuming. After completing the restoration at first the tooth was polished by a composite polishing fissure bur. And the final polishing was given by composite polishing disc according to its color code using polishing paste( Super Snap Rainbow Kit by Shofu)(5).
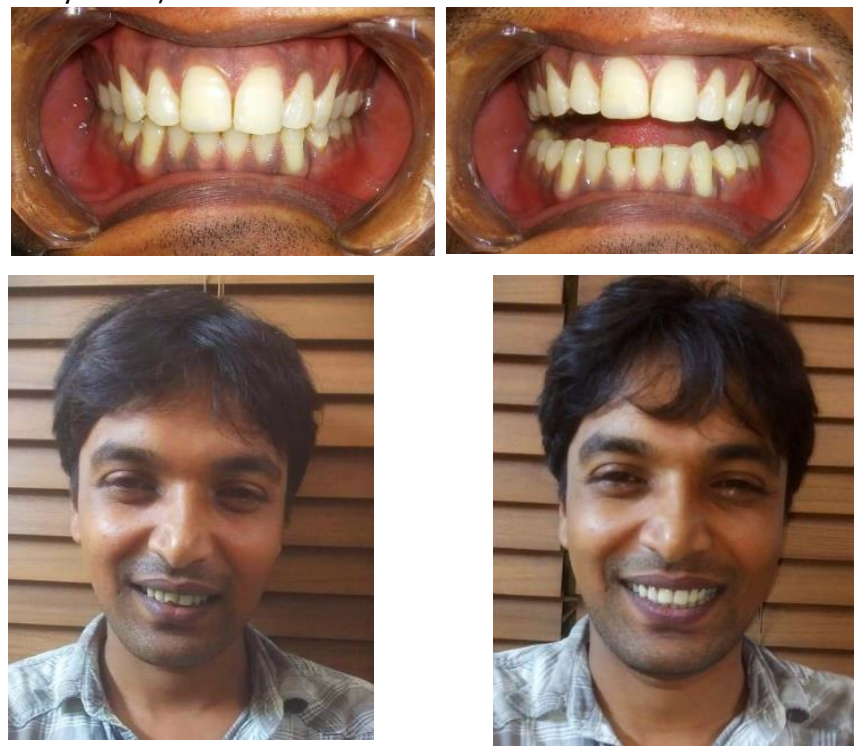

Figure 6: After Final Polishing ( Close View), Figure 7: After Final Polishing ( Open View) Figure 8: Before treatment, Figure 9: After treatment.

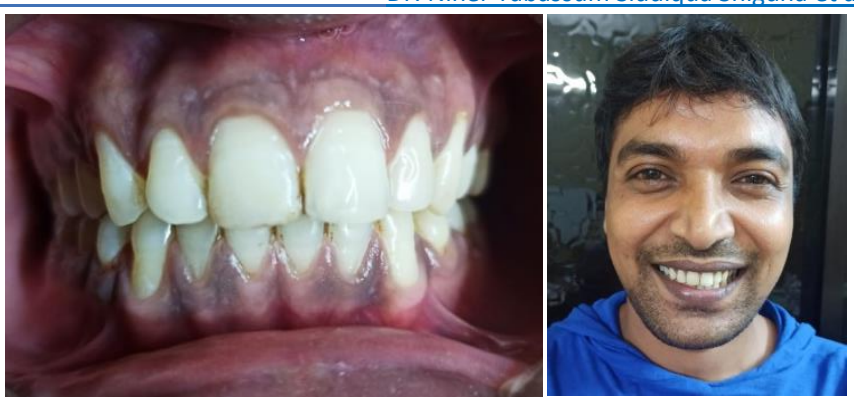

Follow up Images: The patient was in follow-up for 2 years without having any complaint.

\section{DISCUSSION:}

The forecast of a tooth with an uncomplicated crown fracture depends on the pulpal response of the fractured tooth. 2 mechanisms are involved here, one is the dentinal fluid outer flow and another is the response of pulp to any potential inflammation which is enabled by the circulation of an intact pulp ${ }^{(3)}$. In this type of case, the primary objective is to restrict the pulp inflammation to a surface level and prevent bacterial ingress. This is the best archived by an efficient dentin seal(3). Traumatic dental fracture in the anterior segment of the jaw is a tragic incidence for every individual, this experience can hamper the confidence level and performance of the affected persons day to day life.Clinician's main concern is to restore the fractured tooth aesthetically and economically and keeping in mind of patient's systemic and local condition (6). If the fracture fragment of the tooth is available reattachment of that fractured fragment gives the best aesthetic result. But the longevity of such reattachment is questionable due to its tendency to fracture/ deboned. Indirect composite restoration of such fracture results in an extensive risk of both mechanical and biological failure because of extensive tooth preparation ${ }^{(7)}$. Singhal $R$ found $24 \%$ to $51 \%$ variations in reattachment tooth with resistance concerning intact tooth structure.

In the fixed prosthesis, extensive tooth prosthesis extensive tooth preparation can create mechanical and biological failure ${ }^{(7)}$. A mean follow-up of 30 indirect resin composite placed on maxillary anterior teeth has a success rate of $90 \%$ given by Whereas Hemming el al (8). Considering the age and socioeconomic condition of the patient in our case, the fractured tooth is in the occlusion and other symptomfree, an aesthetic and direct composite restoration was planed. Multiple techniques can be considered to restore the fractured tooth which included direct technique or freehand composite restoration. In this case, we performed this technique. Because of its time consuming and cost-effective for the patient.

CONCLUSION:

Restoration of a fractured tooth is a time consuming and complex procedure. The technique offers a simple, quick, and productive treatment option that is also sustainable for the scope of an intermediate procedure can be perfectly recognized only after a long period of observation.

CONFLICT OF INTEREST: Author declared no conflict of interest.

Website: https://www.banglajol.info/index.php/UpDCJ

21|P a g e 
PATIENT CONSENT: Author proclaimed and submitted the patient consent form for profile and other image share for research and journal publishing.

\section{ACKNOWLEDGEMENT:}

I'd like to acknowledge Dr. Md. Ashif labal, working in the Department of Periodontology and Oral Pathology at Update Dental College as an Associate Professor for his guidance to make my references more acceptable by reference linking with DOI number and Pubmed Id (PMid) through Crossref site.

\section{REFERENCES:}

1. Divakar HD, Nayak M, Shetty R. Changing concepts in fracture reattachment of teeth - a case series. Endodontology 2009; 21:46-52.

2. Sikri VK, Textbook of operative dentistry, 4th edition Composites. 2016;17:363-403

3. Olsburgh S, Jacoby T, Krejci I. Crown fractures in the permanent dentition: pulpal and restorative considerations. Dent Traumatol 2002;

18:103-115. https://doi.org/10.1034/j.1600-9657.2002.00004.x PMid:12110103

4. Yilmaz Y, Guler C, Sahin H, Eyuboglu O (2010) Evaluation of tooth-fragment reattachment: a clinical and laboratory study. Dent Traumatol 26(4):308-314. https://doi.org/10.1111/j.16009657. 2010.00907.x https://doi.org/10.1111/i.1600-9657.2010.00907.x PMid:20662883

5. Devices on Nanofilled, Microfilled, and Hybrid Composite: A Scanning Electron Microscopy Yadav RD, Raisingani D, Jindal D, Mathur R. A Comparative Analysis of Different Finishing and Polishing and Profilometric Study. Int $\mathrm{J}$ Clin Pediatr Dent 2016;9(3):201-208

https://doi.org/10.5005/ip-journals-10005-1364

\section{PMid:27843250 PMCid:PMC5086006}

6. Habeeb A, Pasali S. A template aided esthetic rehabilitation of fractured anterior teeth - A case report. Indian journal of research. 2017; 10(6):83- 84.

7. Rajavardhan K, Sai Sankar AJ, Shaik Ahmed Tanveer, Kumar V Naveen, K Raj Kumar. A Novel Technique in Restoring Fractured Anterior Teeth. J Clin Diagn Res. 2014; 8:244-5.

8. Mehta SB, Banerji S, Millar BJ, Suarez Feit J-M. Current Concepts On The Management Of Tooth Wear: Part 4. An Overview Of The Restorative Techniques And Dental Materials Commonly Applied For The Management Of Tooth Wear. British $\begin{array}{lll}\text { Dental Journal. } & 2012 ; & 212: 169-177\end{array}$ https://doi.org/10.1038/sj.bdj.2012.137

PMid:22361546

To submit your manuscript, Mail us to : updci@hotmail.com

To see our latest issue, click the following link https://www.banglajol.info/index.php/UpDCJ 